\title{
Enhanced Elemental Mercury Removal from Coal-fired Flue Gas by Sulfur-chlorine Compounds
}

\author{
Nai-Qiang Yan ${ }^{1,2}$, Zan $\mathrm{Qu}^{1,2}$, Yao $\mathrm{Chi}^{2}$, Shao-Hua Qiao ${ }^{2}$, Ray L. Dod ${ }^{1}$, \\ Shih-Ger Chang ${ }^{1 *}$, Charles Miller ${ }^{3}$
}

Environmental Energy Technology Division, Lawrence Berkeley National Laboratory, University of California, Berkeley, California 94720; School of Environmental Science and Engineering, Shanghai Jiao Tong University, Shanghai 200240; and National Energy Technology Laboratory, Pittsburgh, Pennsylvania 15326

\begin{abstract}
Oxidation of $\mathrm{Hg}^{0}$ with any oxidant or converting it to a particle-bound form can facilitate its removal. Two sulfur-chlorine compounds, sulfur dichloride $\left(\mathrm{SCl}_{2}\right)$ and sulfur monochloride $\left(\mathrm{S}_{2} \mathrm{Cl}_{2}\right)$, were investigated as oxidants for $\mathrm{Hg}^{0}$ by gas phase reaction and by surface-involved reactions in the presence of flyash or activated carbon. The gas phase reaction rate constants between $\mathrm{Hg}^{0}$ and the sulfur/chlorine compounds were determined, and the effects of temperature and the main components in flue gases were studied. The gas phase reaction between $\mathrm{Hg}^{0}$ and $\mathrm{SCl}_{2}$ is shown to be more rapid than the gas phase reaction with chlorine, and the second order rate constant was $9.1( \pm 0.5) \times 10^{-18} \mathrm{~mL}-$ molecules $^{-1} \cdot \mathrm{s}^{-1}$ at $373^{\circ} \mathrm{K}$. Nitric oxide (NO) inhibited the gas phase reaction of $\mathrm{Hg}^{0}$ with sulfur-chlorine compounds. The presence of flyash or powdered activated carbon in flue gas can substantially accelerate the reaction. The predicted $\mathrm{Hg}^{0}$ removal is about $90 \%$ with $5 \mathrm{ppm} \mathrm{SCl}_{2}$ or $\mathrm{S}_{2} \mathrm{Cl}_{2}$ and $40 \mathrm{~g} / \mathrm{m}^{3}$ of flyash in flue gas. The combination of activated carbon and sulfur-chlorine compounds is an effective alternative. We estimate that coinjection of 3-5 ppm of $\mathrm{SCl}_{2}$ (or $\mathrm{S}_{2} \mathrm{Cl}_{2}$ ) with 2-3 Lb/MMacf of untreated Darco-KB is comparable in efficiency to the injection of 2-3 Lb/MMacf Darco-Hg-LH. Extrapolation of kinetic results
\end{abstract}

\footnotetext{
${ }^{1}$ Lawrence Berkeley National Laboratory

${ }^{2}$ Shanghai Jiao Tong University

${ }^{3}$ National Energy Technology Laboratory

* Corresponding author phone: (510) 486-5125; fax: (510) 486-7303; e-mail: sgchang@ @lbl.gov
} 
also indicates that $90 \%$ of $\mathrm{Hg}^{0}$ can be removed if $3 \mathrm{Lb} / \mathrm{MMacf}$ of Darco-KB pretreated with $3 \%$ of $\mathrm{SCl}_{2}$ or $\mathrm{S}_{2} \mathrm{Cl}_{2}$ is used. Unlike gas phase reactions, $\mathrm{NO}$ exhibited little effect on $\mathrm{Hg}^{0}$ reactions with $\mathrm{SCl}_{2}$ or $\mathrm{S}_{2} \mathrm{Cl}_{2}$ on flyash or activated carbon. Mercuric sulfide was identified as one of the principal products of the $\mathrm{Hg}^{0} / \mathrm{SCl}_{2}$ or $\mathrm{Hg}^{0} / \mathrm{S}_{2} \mathrm{Cl}_{2}$ reactions. Additionally, about $8 \%$ of $\mathrm{SCl}_{2}$ or $\mathrm{S}_{2} \mathrm{Cl}_{2}$ in aqueous solutions is converted to sulfide ions, which would precipitate mercuric ion from FGD solution.

\section{Introduction}

Coal-fired power generating plants contribute approximately one third of the mercury released into the environment in the United States. USEPA's Clean Air Mercury Rule (CAMR) of 2005 mandated a transition to capped mercury emissions to be phased in over the next decade. It is possible that more stringent regulations may replace CAMR, which was vacated by the District of Columbia Court of Appeals in 2008. China is similarly interested in reducing mercury emissions from its rapidly increasing number of coal-fired generating plants (1-3).

The mercury is emitted in either oxidized form or as elemental mercury, $\mathrm{Hg}^{0}$, and either in the particulate or vapor phase (3), with the most difficult to control being vapor-phase $\mathrm{Hg}^{0}$, because of its high volatility and low solubility in water. Existing air pollution control devices (APCDs) have demonstrated that some degree of mercury control can be achieved as a co-benefit (3-8). However, the efficiency of mercury removal varies significantly depending on coal rank, flyash properties, and APCD configurations. Particulate mercury can be easily removed by electrostatic precipitators or fabric filters (4), and vapor phase oxidized mercury will usually deposit on particles in the gas stream and be removed with them. A high percentage of any gaseous oxidized mercury remaining in flue gas after particulate removal can be removed in a wet flue gas desulfurization (FGD) system. 
Vapor phase $\mathrm{Hg}^{0}$, being highly volatile and insoluble in water, is not readily removed by existing APCDs. The challenge is to find a cost-effective method to convert the $\mathrm{Hg}^{0}$ to an oxidized or particle-bound form during its short residence time in the ducts before it encounters the APCDs. The $\mathrm{Hg}^{0}$ oxidation methods used for this include heterogeneous catalysis and homogeneous gas phase oxidation (7-14). The catalysts used in Selective Catalytic Reduction (SCR) of $\mathrm{NO}_{\mathrm{x}}$ have shown significant success in mercury oxidation when the chlorine concentration in flue gas is high, such as is typically the case for bituminous coal combustion (7). The lower chlorine content of lower rank coals greatly reduces the efficiency of mercury oxidation by SCR catalysts $(5,8)$. Furthermore, for utilities without SCR apparatus installed, it is not obvious that installation for the sole purpose of removing elemental mercury would be cost effective.

Injection of gaseous oxidants into the flue gas to oxidize $\mathrm{Hg}^{0}$ is relatively simple to implement. The challenge is the selection of the proper oxidants to be utilized (9-14). Given the short residence time of flue gas in the ducts and/or APCDs (typically less than 10 seconds), the reaction between $\mathrm{Hg}^{0}$ and the oxidant(s) needs to be rapid. In addition, the oxidation products need to be stable and environmentally benign. We report here investigation of multifunction oxidants which both oxidize and chemically stabilize the mercury.

Mercuric sulfide is one of the most stable and insoluble of mercury compounds, and thus any process that produces $\mathrm{HgS}$ would meet the product stability test. Elemental sulfur and $\mathrm{H}_{2} \mathrm{~S}$, while readily available, were unable to efficiently oxidize $\mathrm{Hg}^{0}$ within the limited time available. We expected that a sulfur halide would be more active as an oxidant than elemental sulfur, and sulfur mono- and di-chloride are widely used as sulfurating reagents in the rubber industry (15). 
Based on the above considerations, we performed a series of experiments to determine the gas phase reaction rate constants for the oxidation of $\mathrm{Hg}^{0}$ by sulfur chlorides, the effect on the reaction rate of the main components of flue gas (including flyash), and the main reaction products.

\section{Experimental}

\section{Gas phase reaction of $\mathrm{Hg}^{\mathbf{0}}$}

The reaction kinetics and removal efficiency for elemental mercury oxidation were studied with in-situ monitoring of the concentration of $\mathrm{Hg}^{0}$ in the reactor as a function of time by a mercury cold vapor atomic absorption spectrophotometer (CVAAS) described previously $(11,12)$. A reference beam was added to minimize the noise in the monitoring signal, improving the sensitivity of the system.

\section{Reactions involving particles}

With a laboratory scale system it is difficult to evenly disperse fine particles in the gas. Simulation can be achieved by coating the particles on the reactor wall (12), but this introduces a diffusion-limitation factor in processing. In order to minimize the diffusion-limitation factor, a new reactor was developed to test the reaction in the presence of particles (flyash or activated carbon). The reactor is a stainless steel cylinder of $105 \mathrm{~mm}$ inner diameter and a volume of $1100 \mathrm{ml}$. A rotating 6-vane stirrer, driven by a magnetic rotor, was installed inside the reactor. The diameter of the stirrer was $80 \mathrm{~mm}$ and its speed could be varied from 0 to $1500 \mathrm{rpm}$. A thin metal strip (3-10 $\mathrm{mm}$ in width and $80 \mathrm{~mm}$ in length) was fixed to the stirrer to hold the particles which were attached to double coated carbon tape (Ted Pella, Inc.).

To characterize the reactor's behavior, Darco-Hg-LH, a commercial sorbent (brominated powdered activated carbon) which has been widely utilized in field and demonstrations for coal- 
fired mercury capture $(4,14)$, was employed as reference. The amount of activated carbon (Darco-KB or Darco-Hg-LH) or flyash on the carbon tape was approximately $0.12 \mathrm{mg}$ per square centimeter.

\section{Materials and Analysis}

The reactor wall was completely coated with a halocarbon wax (HC, Series-1500) to minimize adsorption and surface effects. The effects of $\mathrm{SO}_{2}, \mathrm{NO}$, and $\mathrm{CO}$ on $\mathrm{Hg}^{0}$ removal were investigated. Sulfur dichloride $\left(\mathrm{SCl}_{2}, 80 \%\right)$ and sulfur monochloride $\left(\mathrm{S}_{2} \mathrm{Cl}_{2},>98 \%\right)$ were from Sigma-Aldrich and Shandong Zibo Chemical plant. Both were purified by distillation before use. Elemental mercury (99.99\%), and chloroform (99.99\%) were from Sigma-Aldrich. Nitric Oxide (>99\%), carbon monoxide(9.8\%) and sulfur dioxide(>99\%) from Matheson Co. and Dalian Date

Standard Gas Co., Halocarbon wax from Halocarbon Product Co., and Darco-KB / Darco-Hg-LH from Norit American Company. A flyash (flyash-L) from burning lignite was tested. The loss of ignition (LOI) and BET surface area of the flyash-L were measured to be $1.3 \%$ and $6.56 \mathrm{~m}^{2} / \mathrm{g}$, and the BET surface area of unburned carbon in flyash-L is calculated to be $398 \mathrm{~m}^{2} / \mathrm{g}$.

The $\mathrm{Hg}^{0}$ concentration in the reactor was measured in situ by CVAAS with a time resolution of 20 milliseconds. The concentration of sulfur dichloride gases was measured with a UV/Vis Spectrometer (Lambda-02, Perkin Elmer) at 195nm, calibrated by FTIR (MAGNA-760, Nicolet) at a wave-number of $525 \mathrm{~cm}^{-1}$ (13). $\mathrm{S}_{2} \mathrm{Cl}_{2}$ was measured by UV/Vis spectroscopy at its maximum absorbance at $258 \mathrm{~nm}$. The uncertainties in the measured concentrations of $\mathrm{Hg}^{0}$ and sulfur chlorides were $\pm 0.005 \mathrm{ppm}$ and $\pm 2 \mathrm{ppm}$, respectively. The accuracy of the data reported here was estimated to be within $20 \%$.

\section{Results and Discussion}




\section{$\mathrm{Hg}^{0}$ Removal by Gas phase reaction}

The oxidation efficiency of elemental mercury by sulfur dichloride and sulfur monochloride as a function of the reaction time is shown in Figure 1. Results for chlorine and elemental sulfur are shown for comparison. As can be seen, both sulfur dichloride and sulfur monochloride were more effective in oxidizing elemental mercury than chlorine gas. When the oxidant concentration was kept around $85 \mathrm{ppm}$, the oxidization efficiencies at a reaction time of 40 seconds were about 3\%, $9 \%$ and $50 \%$ for $\mathrm{Cl}_{2}, \mathrm{~S}_{2} \mathrm{Cl}_{2}$ and $\mathrm{SCl}_{2}$, respectively.

The data shown in Fig.1 show the reactions between $\mathrm{Hg}^{0}$ and the oxidants to have pseudo first-order rate kinetics. The oxidation rate of $\mathrm{Hg}^{0}$ also appears to be directly proportional to the oxidant concentration. Therefore, it can be concluded that the gas phase reactions of $\mathrm{Hg}^{0} / \mathrm{SCl}_{2}$ or $\mathrm{Hg}^{0} / \mathrm{S}_{2} \mathrm{Cl}_{2}$ are second-order with respect to $\mathrm{Hg}^{0}$ and $\mathrm{SCl}_{2}$ or $\mathrm{S}_{2} \mathrm{Cl}_{2}$, as expressed by eq 1 (16): $-d\left[\mathrm{Hg}^{0}\right] / d t=k_{2}[X]\left[\mathrm{Hg}^{0}\right]$

where, $[X]$ denotes the concentration of $\mathrm{SCl}_{2}$ or $\mathrm{S}_{2} \mathrm{Cl}_{2}$, molecules $\cdot \mathrm{mL}^{-1}$ in $\mathrm{N}_{2}$ and $k_{2}$ is the secondorder rate constant. The rate constants from our data are:

$9.1( \pm 0.5) \times 10^{-18} \mathrm{~mL} \cdot \mathrm{molecules}^{-1} \cdot \mathrm{s}^{-1}$ for $\mathrm{Hg} / \mathrm{SCl}_{2}$ and $4.2( \pm 0.5) \times 10^{-19} \mathrm{~mL} \cdot$ molecules $^{-1} \cdot \mathrm{s}^{-1}$ for $\mathrm{Hg} / \mathrm{S}_{2} \mathrm{Cl}_{2}$

at $373 \pm 2{ }^{\circ} \mathrm{K}$ and 760 torr. A second-order rate constant for $\mathrm{Hg}^{0} / \mathrm{Cl}_{2}$ of $1.1( \pm 0.5) \times 10^{-19}$ $\mathrm{mL} \cdot$ molecule ${ }^{-1} \cdot \mathrm{s}^{-1}$ at $373 \pm 2{ }^{\circ} \mathrm{K}$ has been reported (11). The reaction rate constant for $\mathrm{Hg} / \mathrm{SCl}_{2}$ is nearly two orders of magnitude larger than $\mathrm{Hg} / \mathrm{Cl}_{2}$, while the reaction rate constant for $\mathrm{Hg} / \mathrm{S}_{2} \mathrm{Cl}_{2}$ was much less, only about 4 times higher than that of $\mathrm{Hg} / \mathrm{Cl}_{2}$. If the effects of other flue gas constituents are not considered, neither $\mathrm{SCl}_{2}$ nor $\mathrm{S}_{2} \mathrm{Cl}_{2}$, despite having larger reaction rate constants than $\mathrm{Cl}_{2}$, is sufficiently effective in the removal of elemental mercury based solely on gas phase reactions. 


\section{Effect of the reaction temperature}

The thermal stability of $\mathrm{SCl}_{2}$ and the effect of temperature on the rate constant of the $\mathrm{Hg}^{0} / \mathrm{SCl}_{2}$ oxidation were studied. It was found that $\mathrm{SCl}_{2}$ showed good thermal stability up to $400 \mathrm{~K}$, with a loss through thermal decomposition of less than $5 \%$ when it was heated for 300 seconds at $400^{\circ} \mathrm{K}$. Therefore, the loss of $\mathrm{SCl}_{2}$ resulting from thermal decomposition was negligible in our tests since the duration of most were 200 seconds or less.

The temperature dependence of the oxidation efficiency of the reaction of $\mathrm{Hg}^{0} / \mathrm{SCl}_{2}$ is shown in Figure 2. The $\mathrm{Hg}^{0}$ oxidation efficiency decreased with increasing temperature for the gas phase reaction in the range of $297-393^{\circ} \mathrm{K}$. Increasing the temperature from $297{ }^{\circ} \mathrm{K}$ to $393{ }^{\circ} \mathrm{K}$, reduced the oxidation efficiency from $39.3 \%$ to $24.7 \%$ at 30 seconds. A similar behavior was also apparent for $\mathrm{Hg}^{0} / \mathrm{S}_{2} \mathrm{Cl}_{2}$.

\section{$\mathrm{Hg}^{0}$ removal in the presence of fly ash or powdered activated carbon}

\section{Mass transfer and $\mathrm{Hg}^{0}$ removal}

Since many field studies using Darco-Hg-LH as a mercury capture sorbent have been reported, it was used to characterize the performance of the reactor and the method. The BET surface area

of Darco-Hg-LH used was about $520 \mathrm{~m}^{2} / \mathrm{g}$, and which was reduced to $340 \mathrm{~m}^{2} / \mathrm{g}$ when coated onto the carbon tape, a loss of about $35 \%$.

Pieces of carbon tape with areas of $0.7,1.8$ and $4 \mathrm{~cm}^{2}$ were coated with $0.11 \mathrm{mg}, 0.28 \mathrm{mg}$ and $0.62 \mathrm{mg}$ of Darco-Hg-LH, respectively. The coated carbon tapes were mounted on metal strips above and attached to the stirring vanes. The removal efficiency at various rotation speeds is shown in Figure 3. It is apparent that turbulence from the rotating stirrer helped to increase the 
$\mathrm{Hg}^{0}$ removal efficiency in the presence of activated carbon when the rotation speed is low, but higher speeds do not yield proportionate increases. The removal efficiency of $\mathrm{Hg}^{0}$ observed at 15 seconds of contact time was $11.6 \%, 19.8 \%$ and $33.4 \%$ with ratios of Darco-Hg-LH to gas volume of $100 \mathrm{mg} / \mathrm{m}^{3}, 255 \mathrm{mg} / \mathrm{m}^{3}$ and $562 \mathrm{mg} / \mathrm{m}^{3}$, respectively.

The observed depletion of $\mathrm{Hg}^{0}$ from capture by Darco-Hg-LH conformed to a pseudo $1^{\text {st }}$ order rate constant at various rotating speeds. Thus, the mercury capture rate by Darco-Hg- $\mathrm{LH}$ can be described by eq2.

$$
-V \frac{d\left[H g^{0}\right]}{d t}=M \varepsilon K_{g}\left[H^{0}\right]
$$

where, $V$ is the gas volume, $\mathrm{m}^{3} ; M$ is the particles mass in the gas, $\mathrm{g} ; \varepsilon$ is the effective area of the particles, $\mathrm{m}^{2} / \mathrm{g}$; and $K_{g}$ is the overall apparent mass transfer coefficient, $\mathrm{m} / \mathrm{s}$. Thus, the removal efficiency with respect to contact time can be described by eq 3 .

$$
\eta_{\mathrm{t}}=\left[1-\exp \left(-\mathrm{M} \varepsilon \mathrm{K}_{\mathrm{g}} / \mathrm{Vt}\right)\right] \times 100 \%
$$

From the data in Figure $3, \varepsilon \mathrm{K}_{\mathrm{g}}$ at $1500 \mathrm{rpm}$ was approximately $0.032-0.035 \mathrm{~m}^{3} / \mathrm{gs}$.

A demonstration at the $140 \mathrm{MW}$ Meramec Station (4,14), with a feed rate of $3.2 \mathrm{lb} / \mathrm{MMacf}$ $\left(52 \mathrm{mg} / \mathrm{m}^{3}\right)$ of Darco-Hg-LH in flue gas, the total mercury removal efficiency was $93 \%$ using Darco-Hg-LH. Given a gas-solid contact time of $5 \mathrm{sec}$, the estimated $\varepsilon \mathrm{K}_{\mathrm{g}}$ reported in this industrial demonstration was about 6-7 m³/g-s for Darco-Hg-LH, about 200 times greater than that obtained in this study.

The difference of $\varepsilon \mathrm{Kg}$ between this study and the industrial tests can be explained with the gassolid contacting modes. Darco-Hg-LH particles in this test were closely coated on the strip with one side not directly exposed to the bulk gas, which would reduce the chance of the lower surface contacting the gas because there is inevitably a thin boundary layer over the fixed particles. The 
effective gas-solid contact surface was approximately the tape area coated with Darco-Hg-LH. In the large scale experiments, the activated carbon particles were well dispersed in the flue gas, and almost all the surface, including the internal pore surface, of the particles is exposed to the flue gas. This suggests that a correction coefficient of 200 for $\varepsilon \mathrm{Kg}$ can be used to extrapolate the data for activated carbon from this study to a large scale. As a conservative estimate, the correction coefficient of $\varepsilon \mathrm{Kg}$ for flyash was set at 100.

\section{$\mathrm{Hg}^{0}$ removal in the presence of flyash}

Flue gas from pulverized coal boilers can contain $30 \mathrm{~g} / \mathrm{m}^{3}$ or more of flyash depending on mineral content in coal. Therefore, the contribution of flyash to mercury capture in the presence of the oxidant should be investigated. Ten and twenty square centimeter pieces of carbon tape were coated with flyash at approximately $1.2 \mathrm{mg} / \mathrm{cm}^{2}$. Figure 4 shows the removal efficiency of $\mathrm{Hg}^{0}$ with flyash only and with different amounts of $\mathrm{SCl}_{2}$. It can be seen that the $\mathrm{Hg}^{0}$ removal efficiency was significantly greater in the presence of flyash, and it increased with the amount of flyash in the reactor. The difference of the depletion efficiencies between the gas phase reaction and the reaction with flyash can be regarded as the net contribution of flyash. It can be calculated that the $\varepsilon \mathrm{Kg}$ was $0.00015 \mathrm{~m}^{3} / \mathrm{gs}$ and $0.00013 \mathrm{~m}^{3} / \mathrm{gs}$ when $\mathrm{SCl}_{2}$ and $\mathrm{S}_{2} \mathrm{Cl}_{2}$ were at 24 and $22 \mathrm{ppm}$, respectively. Given that $\varepsilon \mathrm{Kg}$ of flyash in the Meramec flue gas was still about as 100 times that

observed in this study, eq. 3 predicts that the $\mathrm{Hg}^{0}$ removal efficiency is about $90 \%$ with $40 \mathrm{~g} / \mathrm{m}^{3}$ of flyash and about $5 \mathrm{ppm}$ of $\mathrm{SCl}_{2}$ or $\mathrm{S}_{2} \mathrm{Cl}_{2}$ in flue gas, most of which was converted to particlebound mercury.

\section{$\mathrm{Hg}^{0}$ removal in the presence of activated carbon}


Figure 5 shows the removal of $\mathrm{Hg}^{0}$ in the reactor with Darco-KB activated carbon. Without oxidants, the removal efficiency of $\mathrm{Hg}^{0}$ by Darco-KB was very slow. However, when about 8ppm of $\mathrm{SCl}_{2}$ or $\mathrm{S}_{2} \mathrm{Cl}_{2}$ was introduced, the removal efficiency increased dramatically, higher than that with the same amount of Darco-Hg- $\mathrm{LH}$. When the concentration of $\mathrm{SCl}_{2}$ was decreased to 4ppm, $\mathrm{Hg}^{0}$ depletion efficiency was still close to Darco-Hg-LH. This indicates that the coinjection of a common powdered activated carbon and $\mathrm{SCl}_{2}$ or $\mathrm{S}_{2} \mathrm{Cl}_{2}$ into flue gas containing elemental mercury was rather effective, and the observed efficiency was far higher than with the two used separately. It was estimated from the result of this study, 3-5ppm of $\mathrm{SCl}_{2}\left(\right.$ or $\left.\mathrm{S}_{2} \mathrm{Cl}_{2}\right)$ combined with about 2-3Lb/MMacf of untreated Darco-KB was comparable in efficiency to Darco-Hg-LH.

Additionally, chemically treated Darco-KB, impregnated with $\mathrm{SCl}_{2}$ or $\mathrm{S}_{2} \mathrm{Cl}_{2}$, was also prepared and investigated. The observed $\mathrm{Hg}^{0}$ removal efficiencies for Darco-KB impregnated with $3 \%$ of $\mathrm{SCl}_{2}$ or $\mathrm{S}_{2} \mathrm{Cl}_{2}$ are also shown in Figure 5. Their performance in capturing $\mathrm{Hg}^{0}$ was just slightly lower than that of Darco-Hg-LH, and about $90 \%$ of $\mathrm{Hg}^{0}$ can be removed if $3 \mathrm{Lb} / \mathrm{MMacf}$ of such pretreated carbon is added to the flue gas.

\section{Effects of other typical constituents in Flue Gas}

The effects of oxygen, water vapor, $\mathrm{SO}_{2}, \mathrm{NO}$ and $\mathrm{CO}$ on the gas phase reaction of $\mathrm{Hg} / \mathrm{SCl}_{2}$ were investigated. Oxygen, $\mathrm{SO}_{2}, \mathrm{CO}$ and water vapor had negligible effect on the gas phase reaction rate constant of $\mathrm{Hg} / \mathrm{SCl}_{2}$, however $\mathrm{NO}$ reduced the $\mathrm{Hg}^{0}$ removal efficiency .

Figure 6 illustrates that NO significantly inhibited the gas phase reaction of $\mathrm{Hg} / \mathrm{SCl}_{2}$. $\mathrm{NO}$ appears to have little effect on the reduction of $\mathrm{Hg}^{0}$ in the presence of flyash or activated carbon alone. The slight decrease of $\mathrm{Hg}^{0}$ removal efficiency by NO in the presence of flyash may be 
attributable to the decrease of the gas phase reaction contribution to the overall removal efficiency.

\section{Analysis of Products and Proposed Reaction Mechanism}

The reaction products of $\mathrm{Hg} / \mathrm{SCl}_{2}$ on the interior surface of the reactor were collected by washing with ethanol and transfered to powdered activated carbon. The powders were coated onto carbon tape and analyzed by XPS. It was found that all mercury on the collected sample was present as $\mathrm{Hg}^{2+}$.

In order to get enough products and to observe the variation in the UV-spectrum during the reaction, a 50ml flask with a magnetic stirrer was employed as a reactor. A drop of elemental mercury (about $0.5 \mathrm{~g}$ ) was introduced to the sealed flask, and the drop was dispersed by the rotating stirrer. Additional $\mathrm{SCl}_{2}$ or $\mathrm{S}_{2} \mathrm{Cl}_{2}$ vapor was quickly introduced into the flask, to an initial concentration of about $2 \%$. The gas constituent variation during the reaction of $\mathrm{Hg} / \mathrm{SCl}_{2}$ was measured with UV-spectroscopy, and it is shown in Figure 7. Initially the concentration of $\mathrm{S}_{2} \mathrm{Cl}_{2}$ was very low, but it increased as $\mathrm{SCl}_{2}$ decreased in the early stages of the reaction, indicating that $\mathrm{S}_{2} \mathrm{Cl}_{2}$ was a significant product of $\mathrm{Hg} / \mathrm{SCl}_{2} . \mathrm{S}_{2} \mathrm{Cl}_{2}$ then decreased as its relatively slower reaction with $\mathrm{Hg}^{0}$ proceeded. Additional $\mathrm{SCl}_{2}$ or $\mathrm{S}_{2} \mathrm{Cl}_{2}$ was added as necessary until the $\mathrm{Hg}^{0}$ was removed. The solid products of $\mathrm{Hg} / \mathrm{SCl}_{2}$ or $\mathrm{Hg} / \mathrm{S}_{2} \mathrm{Cl}_{2}$ appeared to be black or dark gray. In addition, small yellow spots of elemental sulfur mixed with the products were observed and identified.

The product powders produced from the above reactions were analyzed according to their solubility in various solvents. The products were initially heated at about $100^{\circ} \mathrm{C}$ to drive off the unreacted $\mathrm{SCl}_{2}$ or $\mathrm{S}_{2} \mathrm{Cl}_{2}$ absorbed on the powder. This was followed by extraction of sulfur or $\mathrm{S}_{\mathrm{x}} \mathrm{Cl}_{2}$ from the products with carbon disulfide. After drying, mercuric chloride was dissolved 
from the products with ethanol (99.8\%). Finally, a $20 \% \mathrm{Na}_{2} \mathrm{~S}$ solution was used to dissolve mercuric sulfide from the residual product. The weight loss in each washing step was used to calculate the content of sulfur, mercuric chloride and mercuric sulfide in the product. The analysis results for various test conditions are shown in Table 1. It can be seen that $\mathrm{HgS}$ was the main product of $\mathrm{Hg}^{0} / \mathrm{S}_{2} \mathrm{Cl}_{2}$, and its percentage was greater at higher ratios of oxidant to elemental mercury. Though the reaction of $\mathrm{Hg}^{0} / \mathrm{S}_{2} \mathrm{Cl}_{2}$ was slower, it produced a higher percentage of $\mathrm{HgS}$ than did $\mathrm{Hg}^{0} / \mathrm{SCl}_{2}$.

$$
\begin{aligned}
& \mathrm{Hg}^{0}+\mathrm{SCl}_{2} \rightarrow\left[\mathrm{Hg}-\mathrm{SCl}_{2}\right]_{\text {int }} \\
& {\left[\mathrm{Hg}-\mathrm{SCl}_{2}\right]_{\text {int }}+\mathrm{SCl}_{2} \rightarrow \mathrm{HgCl}_{2}+\mathrm{S}_{2} \mathrm{Cl}_{2}} \\
& {\left[\mathrm{Hg}-\mathrm{SCl}_{2}\right]_{\mathrm{int}}+\mathrm{Hg}^{0} \rightarrow \mathrm{HgCl}_{2}+\mathrm{HgS}}
\end{aligned}
$$

This work shows that $\mathrm{SCl}_{2}$ can be effective in oxidizing $\mathrm{Hg}^{0}$ to form mercuric chloride and mercuric sulfide. Although $\mathrm{NO}$ in flue gas can decrease the gas phase reaction rate of $\mathrm{Hg} / \mathrm{SCl}_{2}$, the presence of flyash upstream of the particulate matter control devices can accelerate the oxidation reaction significantly. We expect that $\mathrm{Hg}^{0}$ removal efficiency would be about $90 \%$ with $40 \mathrm{~g} / \mathrm{m}^{3}$ of flyash and about $5 \mathrm{ppm}$ of $\mathrm{SCl}_{2}$ or $\mathrm{S}_{2} \mathrm{Cl}_{2}$ in flue gas.

The addition of powdered activated carbon to sulfur chlorides compounds in flue gas can result in even greater $\mathrm{Hg}^{0}$ removal efficiency. We estimate that co-injection of 3-5 ppm of $\mathrm{SCl}_{2}$ (or $\mathrm{S}_{2} \mathrm{Cl}_{2}$ ) with 2-3 Lb/MMacf of untreated Darco-KB is comparable in efficiency to the injection of 2-3 Lb/MMacf Darco-Hg-LH. Extrapolation of kinetic results also indicates that $90 \% \mathrm{of} \mathrm{Hg}^{0}$ can be removed if $3 \mathrm{Lb} / \mathrm{MMacf}$ of Darco-KB pretreated with $3 \%$ of $\mathrm{SCl}_{2}$ or $\mathrm{S}_{2} \mathrm{Cl}_{2}$ is used. 
Moreover, since $\mathrm{SCl}_{2}$ and $\mathrm{S}_{2} \mathrm{Cl}_{2}$ are soluble in water, the residual amounts are easily absorbed by a wet FGD scrubber. In addition to their abilities to oxidize $\mathrm{Hg}^{0}$ and convert some of $\mathrm{Hg}^{0}$ directly to $\mathrm{HgS}$, sulfide ions were produced in FGD solutions which can precipitate mercuric ion from solution as the very stable $\mathrm{HgS}$, thus reducing the re-emission of mercury from the FGD liquor. The potential of $\mathrm{SCl}_{2}$ or $\mathrm{S}_{2} \mathrm{Cl}_{2}$ to oxidize and stabilize elemental mercury in coal-fired flue gases is clearly promising for further study at a larger scale.

\section{Acknowledgments}

This work was supported by the Assistant Secretary for Fossil Energy, U.S. Department of Energy, under Contract DE-AC02-05CH11231 through the National Energy Technology Laboratory, and was partially supported by the National High Technology Research and Development Program of China (2007AA06Z340) through international cooperation. 


\section{Literature Cited}

1. Davidson R.M.; Clarke L. Trace elements in coal. IEAPER/21, London, UK, IEA Coal Research, Jan., 1996, 60.

2. United Nations Environment Programme (UNEP), Global Mercury Assessment, UNEP Chemicals, Geneva, Switzerland, December, 2002.

3. Jiang, G.B.; Shi, J.B.; Feng, X.B. Mercury Pollution in China. Environ. Sci. \& Technol., 2006, 40, 3673-3678.

4. Jones A P; Hoffman J W; Feeley III T; Murphy J T. DOE/NETL's Phase II Mercury Control Technology Field Testing Program: Preliminary Ecnomic Analysis of Activated Carbon Injection, Environ. Sci. \& Technol. 2007, 41, 1365-1371.

5. Kellie. S.; Cao, Y.; Duan, Y.; Li, L.; Chu, P.; Mehta, A.; Carty, R.; Rile, J. T.; Pan, W. P. Factors Affecting Mercury Speciation in a 100-MW Coal-Fired Boiler with Low-NOx Burners. Energy \& Fuels. 2005, 19, 800-806.

6. Blythe, G.; Richardson, C.; Rhudy, R. Pilot Evaluation of the Catalytic Oxidation of Mercury for enhanced Removal in Wet FGD Systems. In Proceedings of Air Quality III: Mercury, Trace Elements, and Particulate Matter Conference, Arlington, VA, September 912, 2002. Energy and Environmental Research Center, University of Dakota, Grand Fork, North Dakota, Sept. 2002.

7. Presto, A. A.; Granite, E. J. Survey of Catalysts for Oxidation of Mercury in Flue Gas, Environ. Sci. \& Technol., 2006, 40, 5602-5609.

8. Lee, C.; Srivastava, R.K.; Ghorishi, S.B.; Hastings, T.W. Stevens, F.M.. Investigation of selective catalytic reduction impact on mercury speciation under simulated $\mathrm{NO}_{\mathrm{x}}$ emission control conditions, Journal of the Air and Waste Management Association. 2004, 54, 1560- 
1566.

9. Hall, B. Gas phase oxidation of elemental mercury by ozone. Water, Air and Soil Pollution, 1995, 80, 301-315.

10. Kaczur J. Oxidation chemistry of chloric acid in NOx/SOx and air toxic metal removal from gas streams; Environmental Prog.. 1996, 15, 245-254.

11. Yan, N. Q.; Liu, S. H.; Chang, S. G.; Miller, C. Method for the study of gaseous oxidants for the oxidation of mercury gas. Ind. vEng. Chem. Res. 2005, 44, 5567-5574.

12. Liu, S. H.;Yan, N. Q.; Liu, Z. R.; Chang, S. G.; Miller, C. Using bromine gas to enhance mercury removal from flue gas of coal-fired power plants. Environ. Sci. \& Technol., 2007, $41,1405-1412$.

13. Hall, B.; Schager, P.; Lindqvist, P. Experimental study on the rate of reaction between mercury vapour and gaseous nitrogen dioxide. Water, Air and Soil Pollution. 1995, 81, 121134.

14. Feeley, T.J.III; Brickett, L.A.; O'Palko B.A.; Murphy, J.T. Field Testing of Mercury Control Technologies for Coal-Fired Power Plants, DOE/NETL Mercury R\&D Program Review, May, 2005.

15. Gholiv, K.; Eslami, A.; Is sulfur dichloride unstable. Phosphorus, sulfur and silicon. 1996, $1,269-281$.

16. Benson, S.W. The Foundation of Chemical Kinetics. New York, McGraw-Hill Book Co., Inc. 1960. 


\section{Figure Captions}

Figure 1. The $\mathrm{Hg}^{0}$ removal efficiency by sulfur and/or chlorine containing compounds at 1 atm and $373^{\circ} \mathrm{K}$ as a function of reaction time. The initial $\mathrm{Hg}^{0}$ concentration was $0.08 \mathrm{ppmv}$.

Figure 2. The $\mathrm{Hg}^{0}$ removal efficiency by $\mathrm{SCl}_{2}$ or $\mathrm{S}_{2} \mathrm{Cl}_{2}$ at $373^{\circ} \mathrm{K}$ after $30 \mathrm{sec}$ as a function of temperature. The initial $\mathrm{Hg}^{0}$ concentration was $0.08 \mathrm{ppmv}$.

Figure 3. The effect of rotating speed on the $\mathrm{Hg}^{0}$ removal efficiency by $0.11 \mathrm{mg}, 0.28 \mathrm{mg}$, and $0.62 \mathrm{mg}$ of Darco-Hg-LH after $15 \mathrm{sec}$ at $373^{\circ} \mathrm{K}$. The initial $\mathrm{Hg}^{0}$ concentration was $0.08 \mathrm{ppmv}$.

Figure 4. The removal efficiency of $\mathrm{Hg}^{0}$ by flyash combined with $\mathrm{SCl}_{2}$ or $\mathrm{S}_{2} \mathrm{Cl}_{2}$ as a function of reaction time at $373^{\circ} \mathrm{K}$. The initial $\mathrm{Hg}^{0}$ concentration was $0.08 \mathrm{ppm}$ and the rotating speed was $1500 \mathrm{rpm}$.

Figure 5. Comparison of the removal efficiency of $\mathrm{Hg}^{0}$ by conventional untreated PAC (Darco$\mathrm{KB}$ ) combined with sulfur chlorides to that by brominated PAC (Darco-Hg-LH) at $373^{\circ} \mathrm{K}$ as a function of reaction time. The Darco-KB and Darco-Hg-LH were $0.62 \mathrm{~g}$, the initial $\mathrm{Hg}^{0}$ concentration was $0.08 \mathrm{ppmv}$, and the rotating speed was $1500 \mathrm{rpm}$.

Figure 6. The effect of $\mathrm{NO}$ on the removal efficiency of $\mathrm{Hg}^{0}$ by: 1. $\mathrm{SCl}_{2}, 2 . \mathrm{SCl}_{2}$ combined with flyash, and 2. $\mathrm{SCl}_{2}$ with PAC (Darco-KB) after $30 \mathrm{sec}$ and at $373^{\circ} \mathrm{K}$. The initial $\mathrm{Hg}^{0}$ concentration was $0.08 \mathrm{ppmv}$, and the rotating speed was $1500 \mathrm{rpm}$. 
Figure 7. Time dependent UV-spectra of the reaction between $0.5 \mathrm{~g} \mathrm{Hg}^{0}$ and $2 \% \mathrm{SCl}_{2}$ in a $50 \mathrm{ml}$ flask at $298^{\circ} \mathrm{K}$. The maximum absorption peaks of $\mathrm{SCl}_{2}$ and $\mathrm{S}_{2} \mathrm{Cl}_{2}$ were at $192 \mathrm{~nm}$ and $258 \mathrm{~nm}$, respectively. 


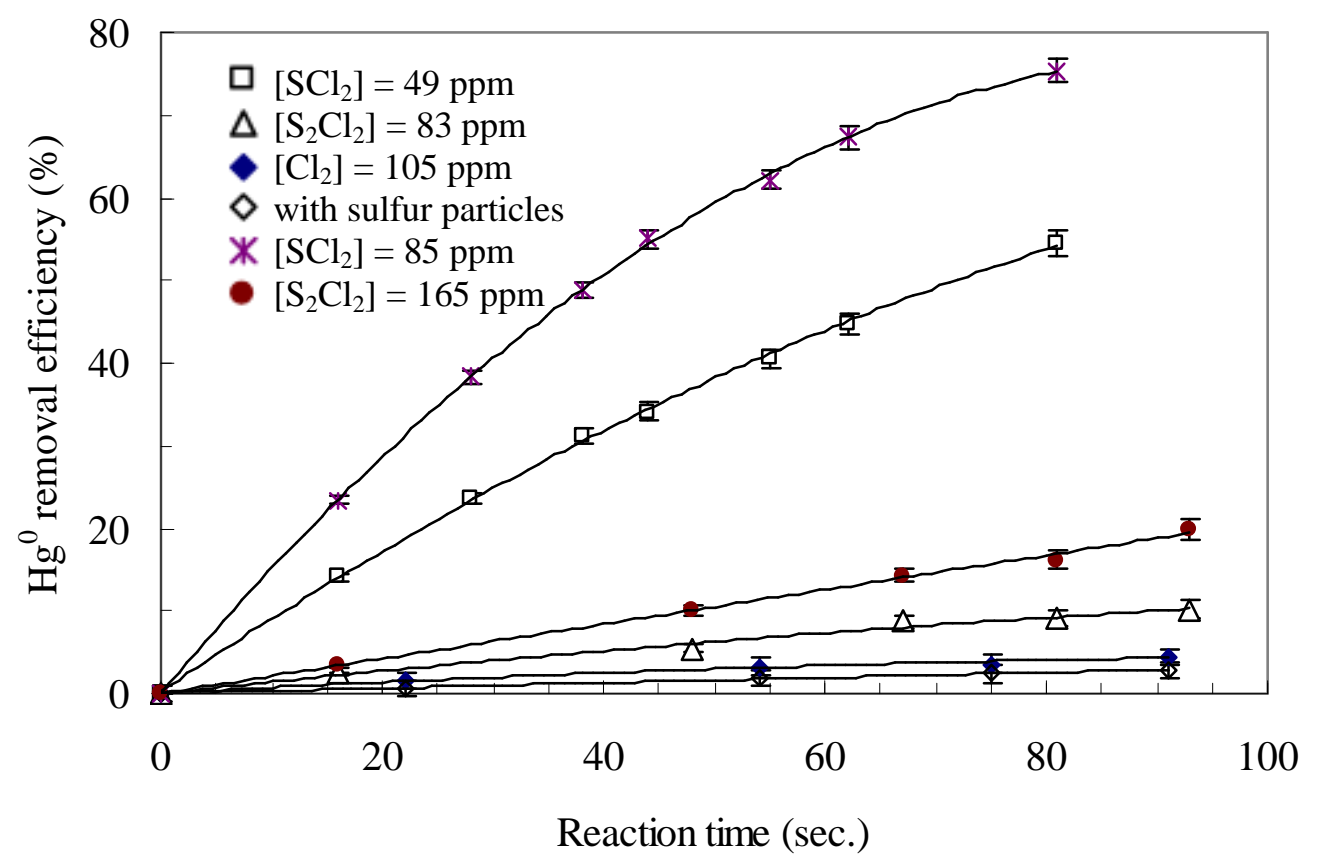

Figure 1. 


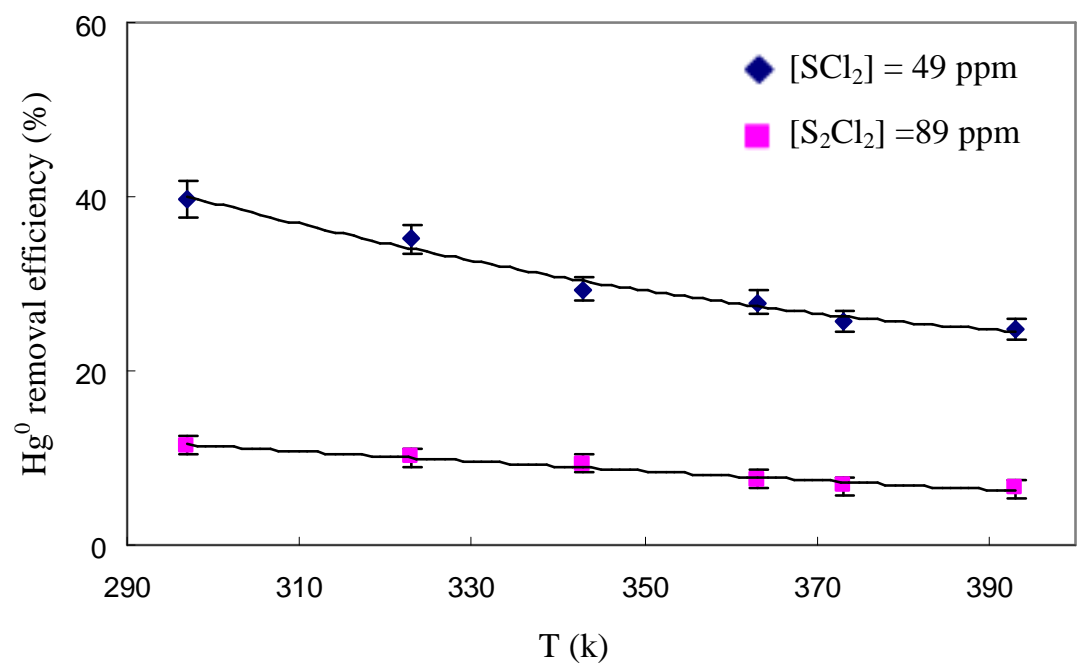

Figure 2. 


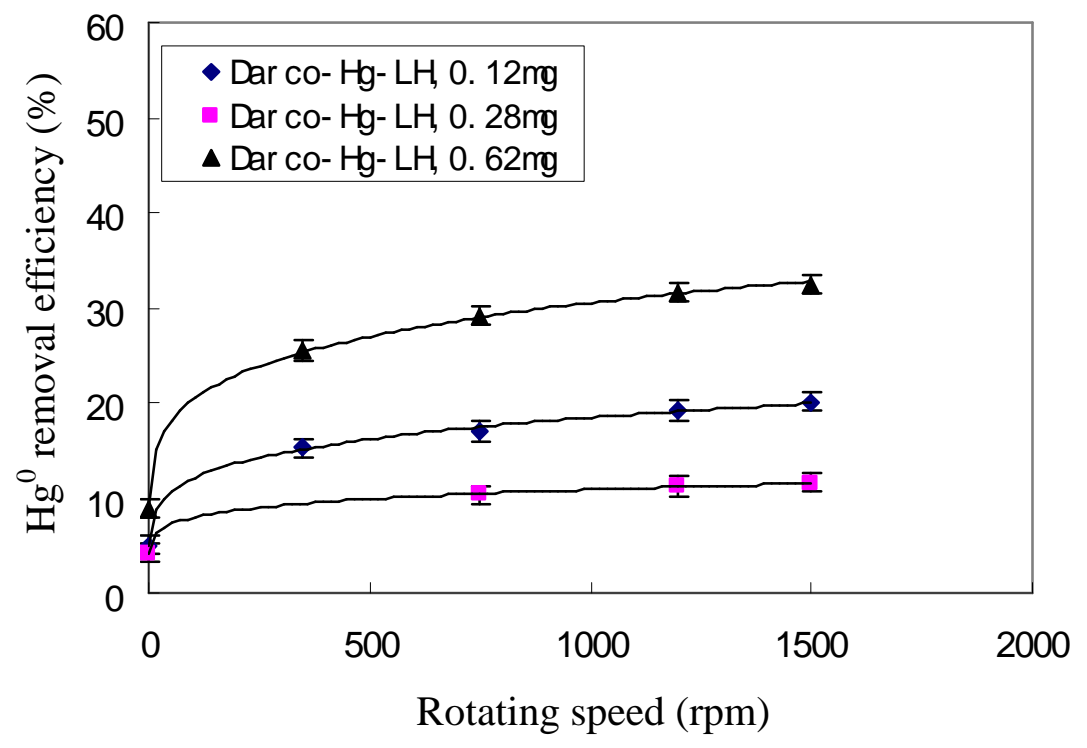

Figure 3. 


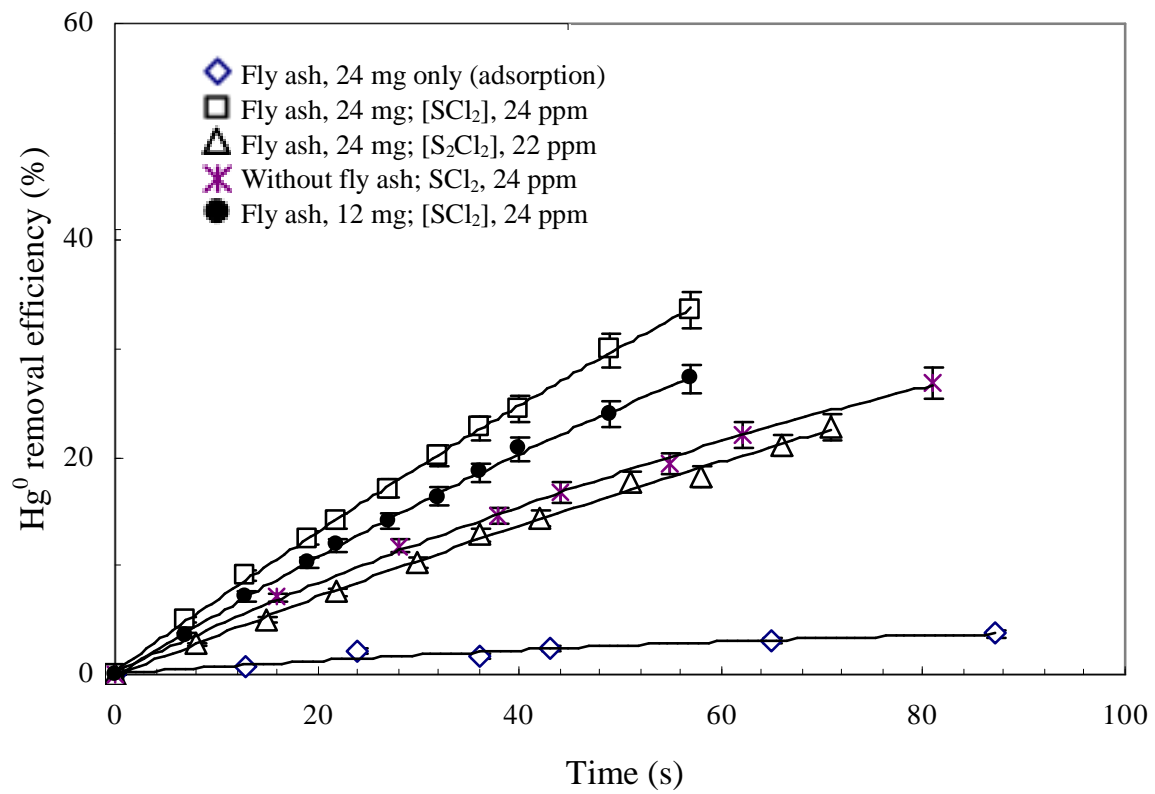

Figure 4. 


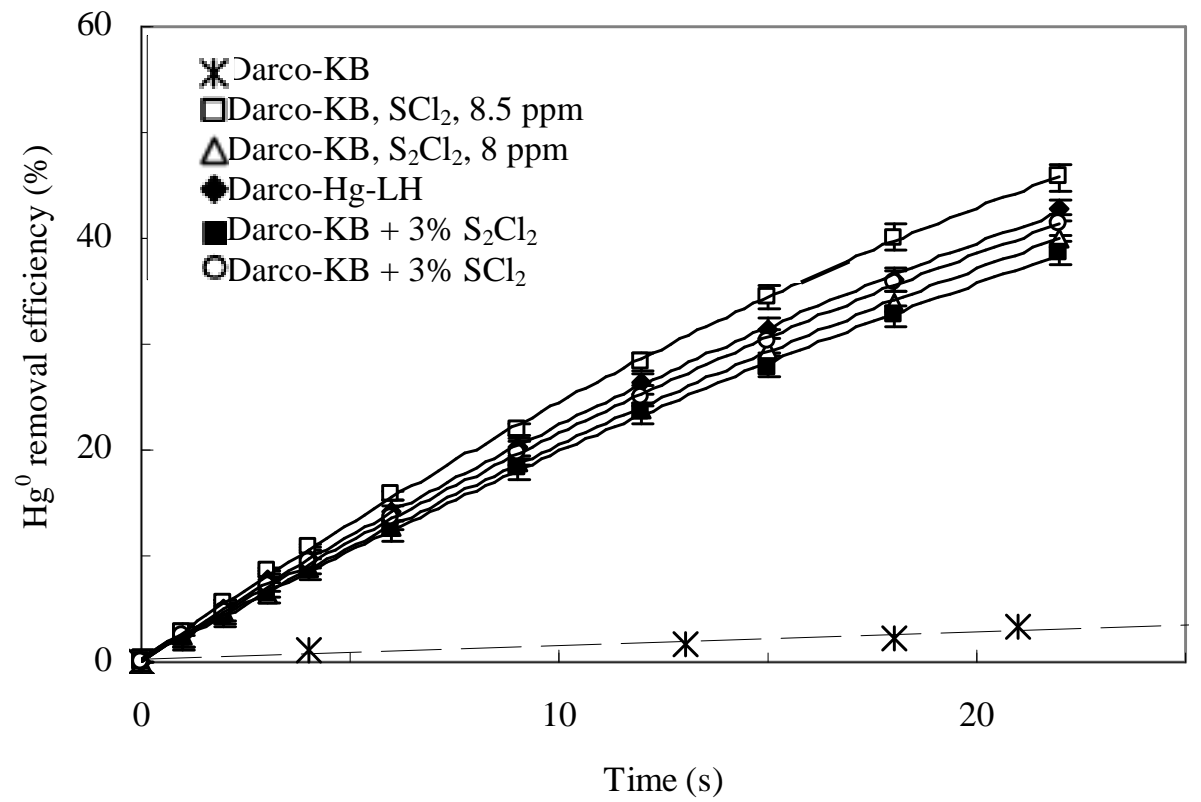

Figure 5. 


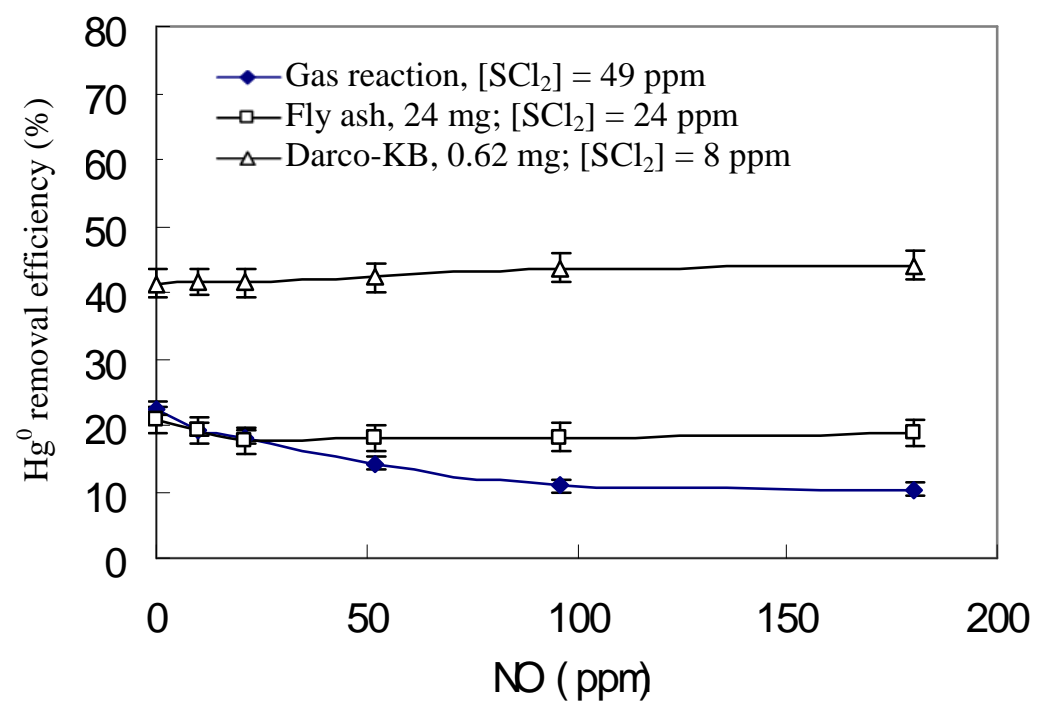

Figure 6. 


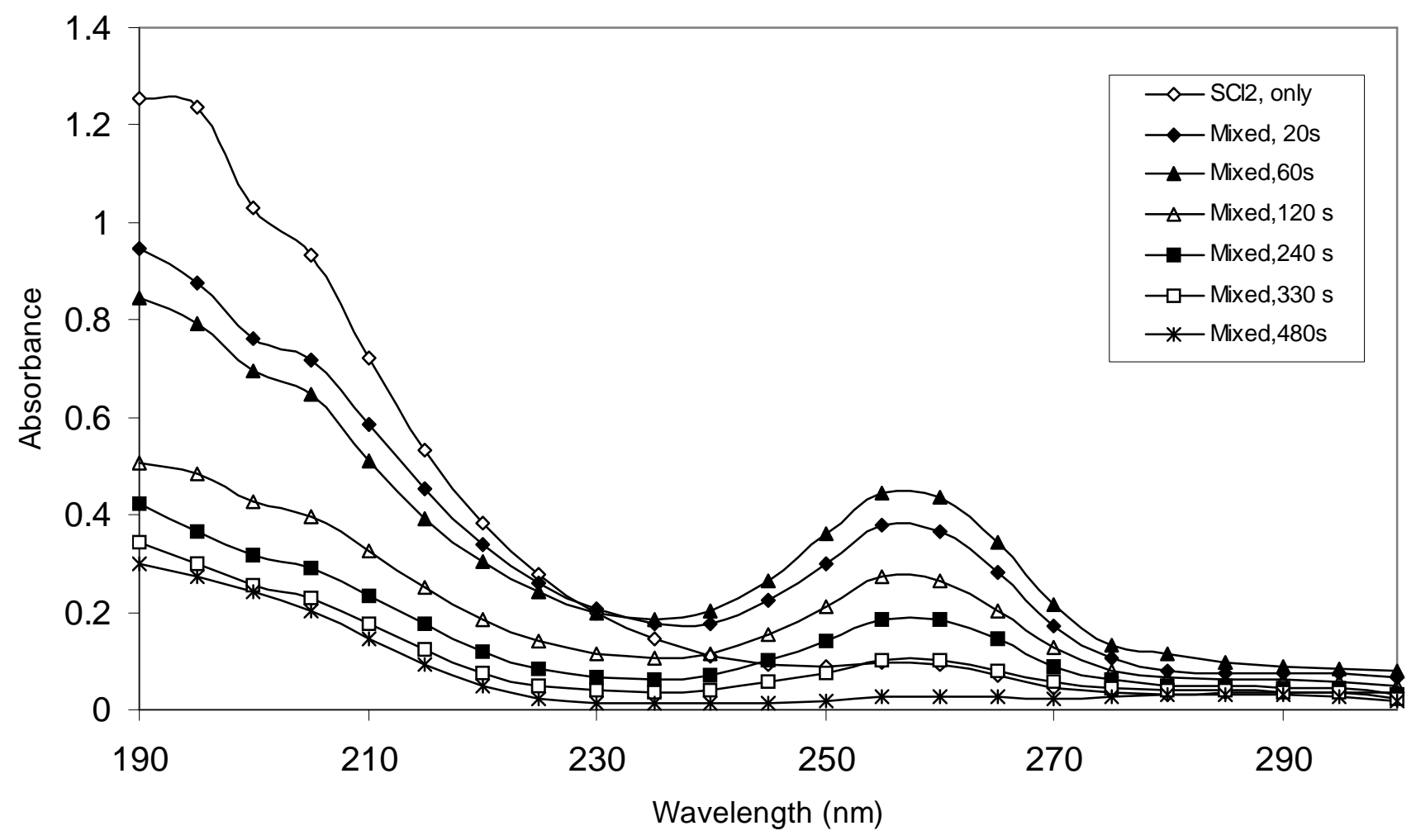

Figure 7. 
Table 1 The distribution of the oxidized mercury at various molar ratios of $\mathrm{SCl}_{2} / \mathrm{Hg}^{0}$ and $\mathrm{S}_{2} \mathrm{Cl}_{2} / \mathrm{Hg}^{0}$.

\begin{tabular}{|l|l|l|}
\hline Reaction condition & $\mathbf{H g C l}_{\mathbf{2}} \mathbf{( \% )}$ & $\mathbf{H g S} \mathbf{( \% )}$ \\
\hline $\mathrm{SCl}_{2}: \mathrm{Hg}^{0}=2.0$ & 74.5 & 25.5 \\
\hline $\mathrm{SCl}_{2}: \mathrm{Hg}^{0}=0.3$ & 46.0 & 54.0 \\
\hline $\mathrm{S}_{2} \mathrm{Cl}_{2}: \mathrm{Hg}^{0}=1.0$ & 12.6 & 87.4 \\
\hline $\mathrm{S}_{2} \mathrm{Cl}_{2}: \mathrm{Hg}^{0}=0.2$ & 31.4 & 68.6 \\
\hline$* \mathrm{Molar}^{0}$ ratio of the oxidant to elemental mercury \\
\hline
\end{tabular}

